\title{
PERUBAHAN SEBARAN SEL-SEL ASIDOFIL DAN BASOFIL HIPOFISA PENGARUH PEMBERIAN PASAK BUMI (Eurycoma longifolia Jack)
}

\author{
Hurip Pratomo (utamahurip@yahoo.com) \\ Univesitas Terbuka \\ Iman Supriatna \\ Wasmen Manalu \\ Dept. Klinik Reproduksi dan Patologi FKH IPB \\ Adi Winarto \\ Dept. Anatomi, Fisiologi, dan Farmakologi FKH IPB
}

\begin{abstract}
Pasak bumi is popular as an aphrodisiac in the traditional medical herb. Boiled drink water of the root powder of pasak bumi is believed can increase the secondary reproduction characters such as libido and the duration of erection. This article is part of the research report that focus on: the distribution of hypophysis acidophil and basophil cells caused of the pasak bumi optimal dose treatment. Research carried out in an experiment using Hemaktosilin Eosin(HE) staining method to study micromorphological distribution of the acidophil and basophil cells of the male rat hypophysis after pasak bumi treatment (the dose of $18 \mathrm{mg}$ pasak bumi/200 $\mathrm{g}$ body weight during three days, and the control of $1 \mathrm{ml}$ aquadest). Result of the research showed that: Basophyl cells increased significantly in the third days of pasak bumi administered. Meanwhile acidophyl cells decreased in the third days of pasak bumi administered.
\end{abstract}

Keyword: pasak bumi, aphrodisiac, hypophysis

Sebagian masyarakat Indonesia mengenal pasak bumi sebagai jamu kuat lelaki (Hembing, 1994). Beberapa sumber menyebutkan bahwa serbuk akar pasak bumi seberat 1 gram dengan air seduhan $100 \mathrm{ml}$ diminum pria dewasa sekali setiap hari selama 3 hari dapat meningkatkan nafsu makan dan libido. (Kardono, Artanti, Dewiyanti, \& Basuki, 2003). Penelitian pada hewan coba yaitu tikus putih menunjukkan hasil yang mendukung fenomena sebagai obat kuat atau afrodisiaka tetapi dengan dosis yang belum jelas (Ang, Lee, 2002).

Pasak bumi menurut beberapa kajian oleh University Science Malaysia mempunyai peranan meningkatkan beberapa karakter seksual, kekuatan dan ukuran otot pada hewan coba dibanding kontrol. Di beberapa negara Asia Tenggara pasak bumi digunakan untuk anti malaria, anti demam, anti peradangan dan sedang diteliti kemungkinannya sebagai suplemen anti kanker. Selain itu, suatu penelitian oleh FRIM (Forest research institute of Malaysia) mendapatkan bahwa pasak bumi mengandung senyawa enzim antioksidan yaitu enzim Superoksida Dismutase. Ektrak air dan metanol dari pasak bumi mempunyai efek menghambat reaksi berantai dari radikal bebas yang dapat membahayakan sistim tubuh (Anonim, 2006).

Peran afrodisiaka juga telah diamati pada tikus jantan tua berumur 24 bulan melalui tingkah laku menguap dan meregangkan tubuh atau "stretching". Hasil percobaan menunjukkan bahwa 800 
mg/kg pasak bumi meningkatkan "yawning" atau menguap sampai 50\% dan tingkah laku "stretching" sampai $16 \%$ pada tikus jantan tua yang lemah seksual. Sedangkan pada tikus jantan yang aktif untuk pembiakan, "yawning" dan "stretching" mencapai 676-719\% dan 31-336\% secara berurutan dibanding perlakuan kontrol. Berdasarkan fenomena tadi disimpulkan bahwa pasak bumi mempunyai peran sebagai afrodisiaka pada tikus putih tua lemah seksual dan tikus jantan aktif (Ang, Lee \& Kiyoshi, 2004).

Penelitian terkini mengenai kerja pasak bumi terhadap tingkah laku libido hewan coba dan dosis terbaik dari variasi dosis tertentu telah dilakukan oleh Pratomo, Adi, dan Edi, (2010). Temuan penelitian tersebut pada tingkah laku libido tikus putih jantan yang menonjol dengan kehadiran betina estrus yang dipisah/disekat jaring kawat di dalam kandang pengamatan adalah: 1) mendekati sekat/betina, 2) bertemu muka/hadapan muka, 3) mengais/menggigit sekat betina. Berkaitan dengan dosis, pemberian pasak bumi dosis seduhan $1=18 \mathrm{mg} / 200 \mathrm{~g}$ bb dalam $1 \mathrm{~m}$ aquades menyebabkan tanggapan/respon libido tertinggi dibanding dosis seduhan $2=100 \mathrm{mg} / 200 \mathrm{~g} \mathrm{bb}$, dosis seduhan $3=$ $200 \mathrm{mg} / 200 \mathrm{~g} \mathrm{bb}$, dan kontrol aquades $1 \mathrm{ml}$.

Dosis seduhan 2 dan 3 mempengaruhi tingkah laku untuk perhatian terhadap lingkungan luar, dalam, dan nafsu makan lebih tinggi daripada dosis seduhan 1 dan kontrol. Tingkah laku tersebut adalah: mengendus sekeliling, mengendus-endus atas, mengais/mendorong sekam dan makan sekam.

Berdasarkan temuan Pratomo, Adi, dan Edi, 2010 diperoleh dua hal penting yaitu: (1) akar pasak bumi dapat digunakan untuk meningkatkan libido, libido adalah salah satu ciri reproduksi sekunder, dan (2) dosis yang terbaik untuk peningkatan libido adalah penggunaan serbuk pasak bumi $18 \mathrm{mg} / 200 \mathrm{~g}$ bb selama 3 hari. Lebih lanjut untuk mengetahui bagaimana kerja pasak bumi dalam kaitannya dengan fungsi reproduksi primer yang masih sedikit sekali informasinya, maka penelitian perlu diteruskan dengan mengkaji organ hipofisa setelah pemberian pasak bumi. Hipofisa diketahui sebagai organ penting yang memproduksi berbagai hormon, diantaranya hormon-hormon reproduksi seperti LH dan FSH yang menjadi komponen utama dan awal dalam jalur siklus fisiologi reproduksi primer pria dan wanita maupun jantan dan betina (Johnson \& Barry, 1998).

Bagian hipofisa yang memproduksi hormon-hormon LH dan FSH adalah pars anterior. Pars anterior dari hipofisa secara mikromorfologi dengan pewarnaan Hematoksilin Eosin (HE) terbagi atas 3 macam sel yaitu: (1) sel kromofob (neutrofil) sukar diwarnai, (2) sel kromatin eosinofilik seperti sel penghasil hormon prolaktin disebut sel asidofil dan (3) sel kromatin basofilik sebagai sel penghasil LH dan FSH disebut selbasofil (Norman, Gerald, 1987; Bergman, 2000).

Berlandaskan beberapa hal tersebut maka penelitian dilanjutkan dengan mengkaji perubahan sebaran sel-sel asidofil dan basofil hipofisa pengaruh pemberian pasak bumi (Eurycoma longifolia Jack). Penelitian ini bertujuan untuk menjelaskan keaktifan sel-sel hipofisa anterior khususnya sel-sel asidofil dan basofil setelah pemberian pasak bumi sampai hari ke 3 . Penelitian diharapkan dapat menunjang informasi ilmiah khasiat pasak bumi yang relatif masih sangat sedikit, khususnya dalam bidang biologi reproduksi. Temuan penelitian secara tidak langsung menunjang perkembangan penggunaan jamu asal Indonesia.

\section{METODE PENELITIAN Hewan coba}

Hewan coba pada penelitian ini menggunakan tikus putih jantan dewasa Rattus norvegicus strain Sprague Dawley berumur $31 \frac{1}{2}$ bulan dengan berat 121-194 g sejumlah 30 ekor diperoleh dari Laboratorium hewan coba Badan POM. Sebelum diberi perlakuan pasak bumi, tikus putih 
diadaptasikan di kandang percobaan laboratorium patologi FKH IPB Bogor selama 2 minggu. Selama penelitian tikus diberi pakan dan minum add libitum.

\section{Bahan serbuk akar pasak bumi}

Prosedur pembuatan simplisia / serbuk bahan akar tanaman pasak bumi (Eurycoma longifolia Jack) seperti pada pembuatan serbuk jamu lainnya (Sinambela, 2003; Pratomo, 1987) dikuliti, dicuci bersih lalu ditiriskan dan dipotong-potong. Potongan dikeringkan dalam oven pada suhu $50^{\circ} \mathrm{C}$ selama 5-7 hari. Potongan akar kayu tersebut lalu digiling sampai halus menggunakan alat giling khusus untuk membuat tepung merk Wiley mill USA, lalu disaring dengan pengayak Mesh 50. Simplisia selanjutnya disimpan dalam toples-toples di lemari kering.

\section{Pemberian/perlakuan dengan pasak bumi}

Pemberian pasak bumi dilakukan 1 kali sehari per oral selama tiga hari dengan dosis seduhan yang menimbulkan libido terbaik temuan Pratomo (2010) yaitu dosis serbuk pasak bumi 18 $\mathrm{mg} / 200 \mathrm{~g}$ berat badan (bb) tikus ditambah air seduhan sejumlah $1 \mathrm{ml}$ seperti terlihat pada Gambar 1.

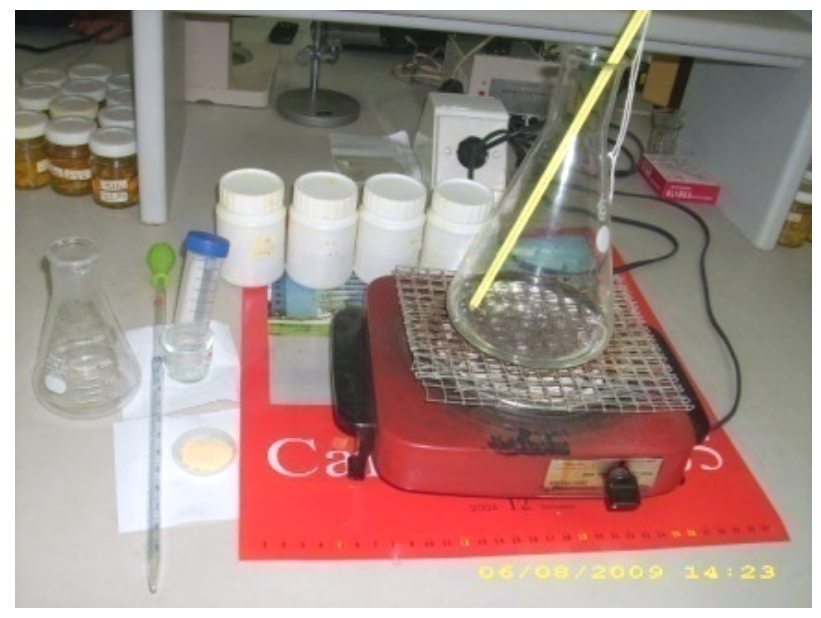

Gambar 1. Pembuatan dosis seduhan pasak bumi

Kontrol dilakukan dengan pemberian aquades $1 \mathrm{ml}$. Sebelum dilakukan pembedahan untuk mengambil hipofisa, kelompok tikus jantan sampling (3 ekor ulangan perlakuan pasak bumi dan 3 ekor ulangan kontrol setiap hari selama tiga hari) dilakukan rangkaian kegiatan sebagai berikut: 1). tikus jantan ditimbang, 2). diberikan seduhan serbuk pasak bumi yang sudah dingin per oral menggunakan sonde dengan dosis sesuai berat badan pada jam 9.00 pagi, 3). Tikus jantan diistirahatkan selama 5 jam di kandangnya, 4). tikus jantan dimasukkan ke dalam kandang percobaan perilaku kelamin/libido selama 10 menit. Kandang percobaan yang digunakan adalah boks plastik yang biasa untuk pengemas buah import berukuran panjang $44 \mathrm{~cm}$, lebar $34 \mathrm{~cm}$, tinggi $17 \mathrm{~cm}$ yang berlubang-lubang di keempat sisi dan atapnya. Kandang tersebut disekat di bagian dalam dengan kawat jaring. Tikus betina yang sedang estrus sebagai penggoda diletakkan di dalam bagian ruang yang sempit $(14 \mathrm{~cm} \times 34 \mathrm{~cm} \times 17 \mathrm{~cm})$ sedangkan tikus putih jantan dimasukkan di bagian yang lebih luas $(30 \mathrm{~cm} \times 34 \mathrm{~cm} \times 17 \mathrm{~cm})$. 5). Setelah 10 menit di dalam kandang percobaan, tikus jantan dikeluarkan dari kandang percobaan lalu dianastesi (dibius) menggunakan Ketamil 100 
$\mathrm{mg} / \mathrm{m}$ dengan dosis $0,2 \mathrm{cc}$ untuk 100-200 $\mathrm{g} \mathrm{bb}$. Langkah selanjutnya dilakukan pembedahan bagian otak untuk pengambilan sampel/sampling jaringan hipofisa. Penggunaan tikus sebagai berikut:

Hari ke $1 \rightarrow 9$ ekor tikus $\hat{\sigma}$ diberikan pasak bumi, 3 ekor untuk sampling jaringan.

Hari ke $2 \rightarrow 6$ ekor tikus $\widehat{\jmath}$ diberikan pasak bumi, 3 ekor untuk sampling jaringan.

Hari ke $3 \rightarrow 3$ ekor tikus $\widehat{\jmath}$ diberikan pasak bumi, 3 ekor untuk sampling jaringan.

\section{Pengambilan sampel jaringan} berikut Tabel 1.

Pengambilan sampel jaringan hipofisa pada hari 1, 2, dan 3 dilakukan seperti rancangan

Tabel 1 Rancangan kegiatan pengambilan sampel jaringan hipofisa

\begin{tabular}{|c|c|c|c|c|}
\hline Waktu & PkI 9.00 WIB & Selang 5 jam & Pkl. 14.00 WIB & PkI 14.12 WIB \\
\hline Hari 1 & $\begin{array}{l}\text { Pemberian } \\
\text { pasak bumi }\end{array}$ & Tikus ð̋istirahat & $\begin{array}{l}\text { Pengamatan tingkah laku } \\
10 \text { menit }\end{array}$ & $\begin{array}{l}\text { Anastesi sampling } \\
\text { Jaringan (bedah) }\end{array}$ \\
\hline Hari 2 & $\begin{array}{l}\text { Pemberian } \\
\text { pasak bumi }\end{array}$ & Tikus ठ̂istirahat & $\begin{array}{l}\text { Pengamatan tingkah laku } \\
10 \text { menit }\end{array}$ & $\begin{array}{l}\text { Anastesi, sampling } \\
\text { Jaringan (bedah) }\end{array}$ \\
\hline Hari 3 & $\begin{array}{l}\text { Pemberian } \\
\text { pasak bumi }\end{array}$ & Tikus ð̋istirahat & $\begin{array}{l}\text { Pengamatan tingkah laku } \\
10 \text { menit }\end{array}$ & $\begin{array}{l}\text { Anastesi, sampling } \\
\text { Jaringan (bedah) }\end{array}$ \\
\hline
\end{tabular}

Sebelum dilakukan sampling jaringan, tikus putih dianastesi intra peritoneal dengan Ketamine $100 \mathrm{mg} / \mathrm{m}$ dengan dosis 0,2 cc untuk 100-200 g bb. Sampel organ hipofisa diambil dari pembedahan tengkorak kepala tikus putih jantan yang telah dibius/anastesi total. Formasi hipofisa terletak di bagian terbawah, di bawah hipotalamus. Bentuk hipofisa tikus seperti barbel dengan ukuran lebih kecil dari kepala/pentul korek api dan bersifat lunak, sehingga pengambilan menggunakan pinset halus di bawah mikroskop histo (pembesaran $10 \mathrm{x}$ ) dilakukan secara sangat hati-hati. Setiap sampel hipofisa diletakkan di dalam tabung ependof kecil yang diisi larutan fiksasi, lalu diberi label (Gambar 2).

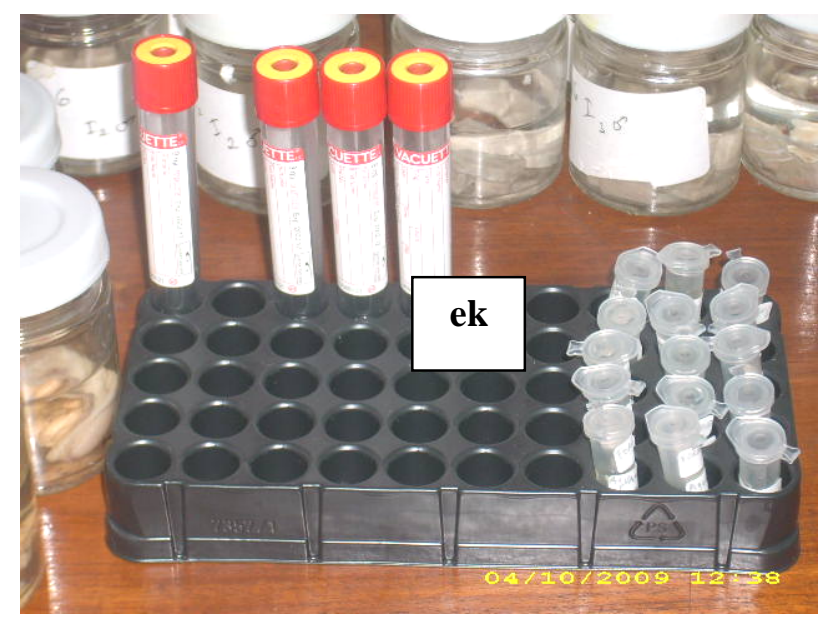

Gambar 2. Hipofisa difiksasi di dalam tabung-tabung ependof kecil (ek). 
Semua sampel jaringan yang diperoleh difiksasi dalam larutan Formaldehid $4 \%$ dalam $\mathrm{NaCl}$ fisiologis 0,9\% disimpan selama 1 minggu dan selanjutnya dilakukan tahapan untuk evaluasi secara histologis (analisis mikromorfologi).

\section{Evaluasi histologis atau analisis mikromorfologi}

Setelah jaringan sampel difiksasi selama 1 minggu, di-clearing dengan xylol dan dibloking dengan parafin histo, lalu disimpan dalam lemari pendingin beberapa hari. Analisis mikromorfologi dilakukan terhadap keaktifan sel-sel hipofisa anterior melalui pendekatan profil sebaran sel-sel asidofil dan basofil. Sel-sel asidofil dan basofil berperan dalam memproduksi hormon-hormon antara lain $\mathrm{LH}$ dan FSH setelah pemberian pasak bumi dikaji dengan pewarnaan $\mathrm{HE}$.

\section{Prosedur sebelum melakukan pewarnaan HE (8 tahap)}

1. Trimming: Potongan sampling organ dipotong tipis setebal $2-3 \mathrm{~mm}$ sesuai besarnya organ sehingga diperoleh jaringan sampel. Organ seperti hipofisa tidak dipotong lagi karena ukurannya yang kecil dan sifat jaringannya sangat lunak. Potongan-potongan tipis 2-3 mm sampling ditaruh dalam basket histo (Gambar 3), lalu direndam di dalam Paraformaldehid 4\% dalam $\mathrm{NaCl}$ fisiologis 0,9\%. Perendaman bersifat fiksasi di dalam basket histo dilakukan 4-7 hari. Basket histo diberi label menggunakan pensil 2B.

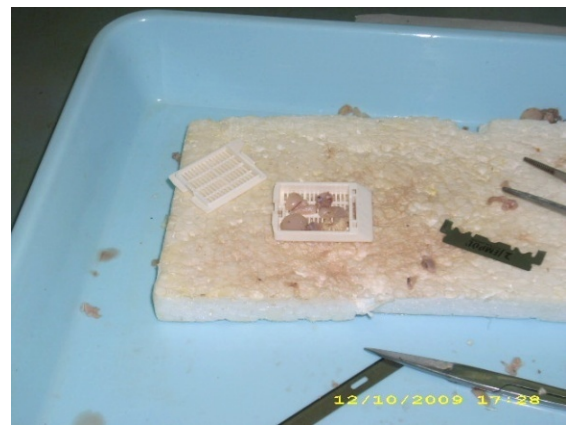

Gambar 3. Trimming, organ selain hipofisa di letakkan di basket histo.

2. Dehidrasi: Basket histo dan isi sampling dipindahkan ke wadah botol/tabung bertutup yang berisi alkohol 70\%, direndam selama 3 jam lalu ke konsentrasi alkohol lebih tinggi secara bertingkat yaitu 80\%, 90\%, 95\%, masing-masing 3 jam dilanjutkan ke tabung alkohol absolut 1 , 2, 3 masing-masing 1 jam (Gambar 4).

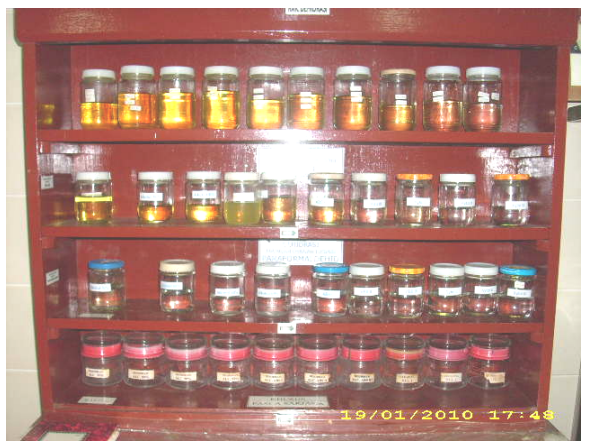

Gambar 4. Tabung-tabung perendaman untuk tahapan dehidrasi dan clearing 
3. Clearing: Melanjutkan tahapan dehidrasi dengan perendaman basket histo berisi sampling ke dalam tabung bertutup berisi larutan Xylol 1, 2, dan 3 masing-masing 40 menit. Basket histo di dalam langkah perendaman Xylol 3 hanya direndam 20 menit, dilanjutkan dengan meletakkan ke dalam inkubator selama 20 menit pada suhu $65^{\circ} \mathrm{C}$. Pemindahan dilakukan di luar inkubator yaitu di atas mesin pemanas parafin ada bagian yang bersuhu hangat. Basket dibuka, sampling diambil dengan pinset khusus parafin dan dipindah ke tabung/botol parafinasi. Botol parafin diberi label, jumlah botol parafin disesuaikan dengan kebutuhan. Label berisikan nama potongan sampling, macam perlakuan, tanggal pembuatan.

4. Parafinasi: Potongan sampling direndam dalam botol berisi parafin histo cair secara bertahap yaitu parafin 1, 2, dan 3 masing-masing 40 menit di dalam inkubator.

5. Embeding: Potongan sampling yang telah diparafinasi dibekukan dalam wadah cetakan parafin yang berbentuk kotak atau mangkuk ceper. Pembekuan dilakukan dengan mengisi cairan parafin menggunakan mesin parafin ke dalam wadah kotak atau mangkuk ceper hingga penuh lalu meletakkan potongan jaringan sampling ke dalamnya (Gambar 5). Wadah yang telah terisi didinginkan dengan diangin-anginkan lalu ditaruh di atas air. Setiap wadah diberi kertas label.

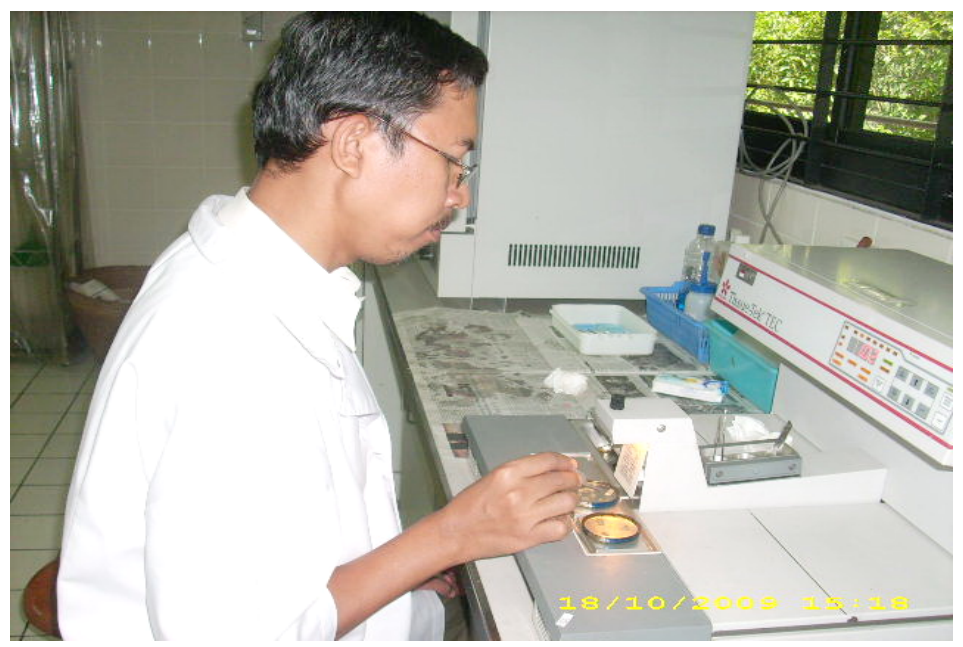

Gambar 5. Tahapan embeding

6. Blocking: Hasil embeding dipotong/dibentuk kotak dengan tetap melindungi potongan sampling, lalu di tempelkan ke kayu alas yang berguna untuk pegangan ketika akan dipotong di alat mikrotom. Penempelan menggunakan skalpel panas. Setiap block kayu berparafin yang berisi potongan sampling di beri label.

7. Pemotongan sampling untuk pembuatan slide: Block parafin berisi potongan sampling dipotong setebal $4 \mu \mathrm{m}$ dengan menggunakan alat mikrotom. Sebelum dipotong block tersebut diletakkan pada bantal es. Setelah diperoleh potongan slide sampling yang baik diapungkan pada air hangat dan ditempelkan pada kaca objek. Setiap kaca objek/slide sampling diberi label dan ditaruh dalam kotak preparat disimpan dalam inkubator $40{ }^{\circ} \mathrm{C}$ selama beberapa hari sampai 1 minggu.

8. Deparafinasi dan rehidrasi untuk HE: Kaca objek/slide berisi jaringan sampling diletakkan ke dalam rak pencelupan untuk pewarnaan lalu dilakukan deparafinasi dan dehidrasi dengan cara memindahkan perendaman dari satu tabung ke tabung lain sebagai berikut: Xylol 3, 2, 1, lalu 
tabung alkohol absolut 3, 2, 1, selanjutnya ke tabung alkohol 95\%, 90\%,80\%, 70\%, waktu perendaman masing-masing 1-2 menit.

\section{Langkah Pewarnaan HE (Hematoksilin Eosin)}

Langkah-langkah pewarnaan HE (Kiernan, 1990) adalah sebagai berikut:

Deparafinasi - rehidrasi (1-2 menit), direndam di air kran selama 10 menit, lalu rendam dalam DW (Destilated water/Aquadest) selama 3-5 menit. Pewarnaan dengan hematoksilin dilakukan selama 2-5 menit. Dilanjutkan dengan pemucatan warna Hematoksilin (diferensiasi) dengan asam alkohol $(1 \% \mathrm{HCl}$ dalam $70 \%$ alkohol) dan air, proses ini dikontrol di bawah mikroskop. Perendaman di air kran selama 10 menit, atau di DW selama 5 menit.

Pewarnaan dengan eosin dilakukan selama 2 menit, atau 15 menit atau overnight (semalam) untuk eosin tertentu. Pemucatan warna eosin sekaligus proses dehidrasi dengan alkohol dan clearing dengan Xylol dilakukan secara bertingkat menggunakan alkohol 70\%, 80\%, 90\%, 95\%, 100\%/absolut 1, 2, 3 lalu xylol 1, 2, 3 masing-masing dengan 3 kocokan kesamping tiap 3 detik (Gambar 6) lalu dikontrol di bawah mikroskop. Langkah terakhir pewarnaan HE, di mounting dengan Entelan (Merck).

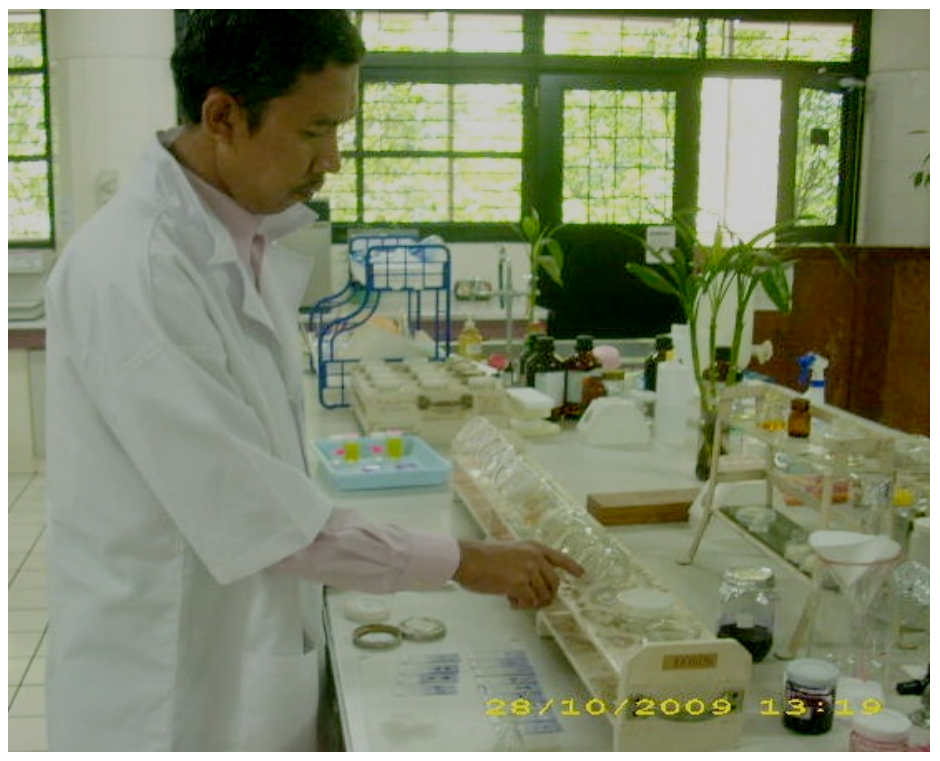

Gambar 6. Clearing di dalam gelas xylol 1, 2,3.

\section{PengukuranPenghitungan distribusi sel sel asidofil dan basofil pada Hipofisa}

Slide preparat hipofisa yang telah diwarnai dengan pewarnaan $\mathrm{HE}$, diamati di bawah mikroskop pembesaran 400 kali (10x pada lensa okuler, 40 x pada lensa objektif). Selanjutnya dicatat jumlah sel asidofil dan sel basofil di dalam populasi 50 sel hipofisa. Penghitungan jumlah kepadatan/sebaran sel asidofil dan basofil dilakukan pada sepuluh area lapang pandang dari sejumlah slide ulangan yang dipilih. Penghitungan dimulai dari titik paling atas lingkaran populasi 50 sel dilanjutkan ke kanan memutar sesuai arah jarum jam terus melingkar ke arah dalam. Data kemudian dihitung reratanya untuk setiap perlakuan. Perlakuan yang dilakukan analisis untuk respon sel hipofisa yaitu: perlakuan pertama adalah pemberian aquades $1 \mathrm{ml}$ pada hari 1; perlakuan kedua 
adalah pemberian aquades $1 \mathrm{ml}$ sampai hari ke 3; perlakuan ketiga adalah pemberian dosis seduhan $18 \mathrm{mg} / 200 \mathrm{~g}$ bb pasak bumi hari 1; dan perlakuan keempat adalah pemberian dosis seduhan 18 $\mathrm{mg} / 200 \mathrm{~g}$ bb pasak bumi sampai hari ke 3 .

Data yang diperoleh dari pewarnaan HE menunjukkan kerja sel-sel endokrin pada hipofisa secara umum. Analisis mikromorfologi menunjukkan sebaran sel-sel asidofil dan basofil yang dapat diperbandingkan antara perlakuan kontrol dan pasak bumi pada hari 1 sampai hari ke 3. Data tersebut dianalisis dengan Anova, dan dilanjutkan dengan uji Duncan.

\section{HASIL DAN PEMBAHASAN}

\section{Sebaran/Distribusi sel-sel asidofil dan basofil pada hipofisa}

Respon sel-sel pada hipofisa diamati setelah pemberian seduhan pasak bumi dosis terbaik hasil dari kajian tahap I yaitu dosis seduhan pasak bumi $=18 \mathrm{mg} / 200 \mathrm{~g}$ bb dalam $1 \mathrm{ml}$ aquades. Kajian mikromorfologi sel-sel hipofisa tikus putih jantan yang diamati adalah pada tiap perlakuan. Hasil analisis sebaran/distribusi sel-sel asidofil dan basofil dari setiap kelompok 50 sel hipofisa ditampilkan reratanya pada Tabel 2.

Tabel 2. Sebaran jumlah sel-sel asidofil dan basofil pada hipofisa setelah perlakuan pasak bumi dan kontrol/aquades pada hari 1 sampai hari ke 3 .

\begin{tabular}{|c|c|c|c|}
\hline Perlakuan & $\begin{array}{l}\text { Asidofil } \\
\text { (rerata) }\end{array}$ & $\begin{array}{l}\text { Basofil } \\
\text { (rerata) }\end{array}$ & \\
\hline Aquades hari 1 & 21,2 a & 28,8 & a \\
\hline Aquades hari 3 & 21,9 a & 28,1 & a \\
\hline Pasak bumi hari 1 & 22,1 a & 27,9 & a \\
\hline Pasak bumi hari 3 & 14,8 b & 35,2 & $b$ \\
\hline
\end{tabular}

Sebaran sel hipofisa diidentifikasi dengan pewarnaan HE dapat mengenali sel-sel asidofil dan basofil. Sel-sel asidofil merupakan sel-sel yang menyerap warna asam dari HE sehingga akan tampak sitoplasmanya berwarna merah muda cerah, secara keseluruhan sitoplasma sel-sel asidofil bersifat basa sehingga mengikat pewarna asam. Sedangkan sel-sel basofil merupakan sel-sel yang menyerap warna basa dari HE sehingga akan tampak sitoplasmanya berwarna keunguan atau kebiruan, secara keseluruhan sitoplasma sel-sel basofil bersifat asam sehingga mengikat pewarna basa. 


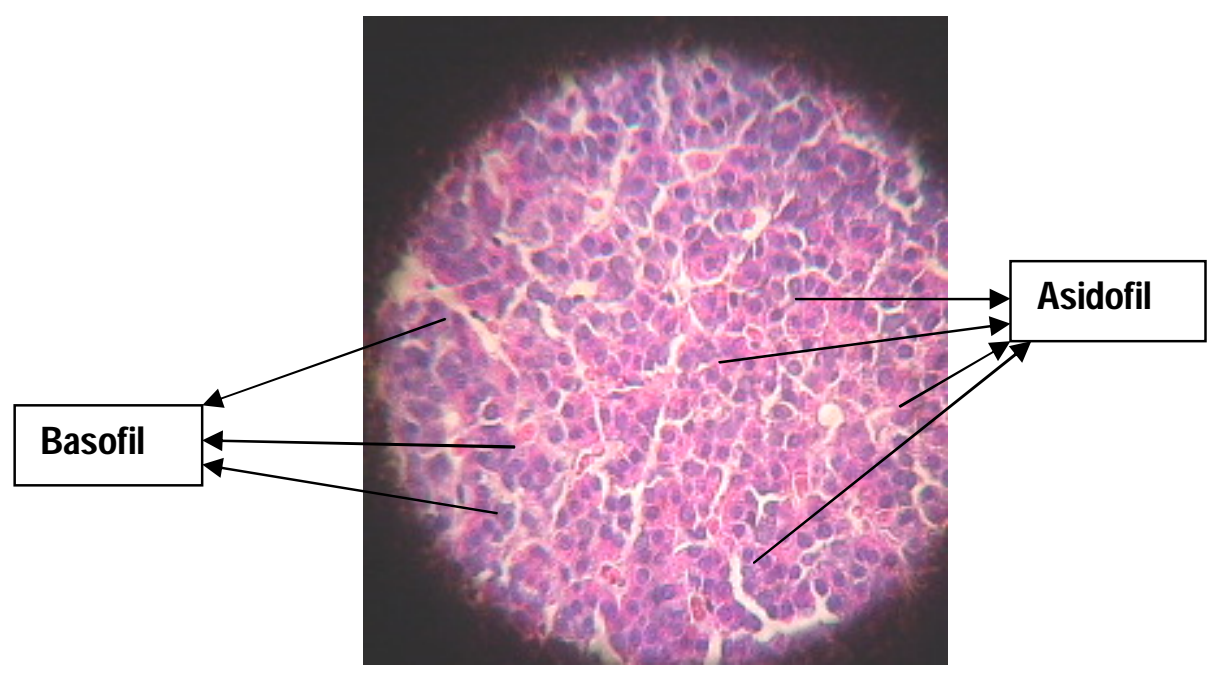

Gambar 7. Sel-sel asidofil dan basofil pada hipofisa perlakuan kontrol hari 1

Sebaran sel asidofil pada hipofisa dengan perlakuan kontrol/aquades pada hari 1 (Gambar 7) sampai hari 3 (Gambar 8) terjadi sedikit peningkatan yaitu dari rerata 21,2 sel menjadi 21,9 sel tetapi tidak signifikan secara statistik (uji Duncan, $\alpha=0,05$ ). Sebaran sel asidofil pada hipofisa dengan perlakuan pasak bumi dosis $18 \mathrm{mg} / 200 \mathrm{~g}$ bb pada hari 1 sampai hari 3 terjadi penurunan yaitu dari rerata 22,1 sel menjadi 14,8 sel yang secara statistik dengan uji Duncan berbeda nyata (uji Duncan, $a=0,05$ ).

Sebaliknya sebaran sel basofil pada hipofisa dengan perlakuan kontrol/ aquades pada hari 1 sampai hari 3 terjadi sedikit penurunan yaitu dari rerata 28,8 sel menjadi 28,1 sel tetapi tidak signifikan secara statistik (uji Duncan taraf nyata 5\%, $a=0,05$ ). Sedangkan sebaran sel basofil pada hipofisa dengan perlakuan pasak bumi dosis seduhan $18 \mathrm{mg} / 200 \mathrm{~g}$ bb pada hari 1 sampai hari 3 terjadi peningkatan secara signifikan yaitu dari rerata 27,9 sel menjadi 35,2 sel (uji Duncan, $a=$ $0,05)$ (Gambar 8). Sehingga pada temuan analisis mikromorfologi ini dapat dikatakan bahwa pasak bumi merupakan pemacu/perangsang yang cukup kuat untuk aktifasi kerja sel-sel basofil pada hipofisa.

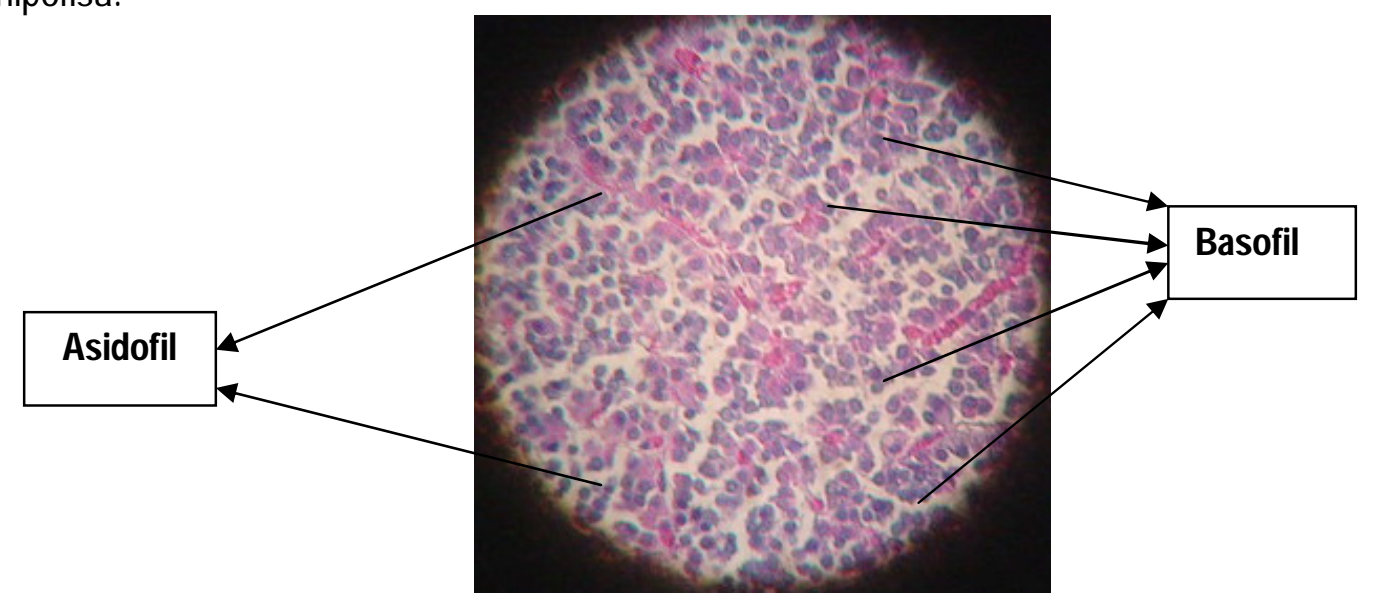

Gambar 8. Sel-sel asidofil dan basofil pada hipofisa perlakuan pasak bumi sampai hari 3 
Hipofisa anterior adalah lobus anterior dari hipofisa yang merupakan bagian paling besar dan penting dari organ hipofisa. Pada mamalia dan manusia lobus ini kira-kira hampir 70\% dari berat total kelenjar. Hipofisa anterior secara histologi terdiri atas sel-sel epitel kelenjar dari berbagai ukuran dan bentuk tersusun dalam jalur-jalur yang relatif luas dan sirkuler serta dipisahkan oleh saluransaluran yang mengandung darah. Hipofisa dengan pewarnaan HE dibedakan atas tiga jenis sel yaitu: (1) sel kromofob (neutrofil) sukar diwarnai, (2) sel kromatin mengambil warna asam (eosinofil) seperti sel penghasil prolaktin adalah asidofilik dan (3) sel kromatin mengambil warna basa (basofil). Sel penghasil LH dan FSH adalah sel endokrin yang bersifat basofilik dan disebut sel-sel basofil. Sel-sel kromatin terletak di luar jalur dan oleh karena itu berdekatan dengan saluran-saluran pembuluh kapiler darah dan relatif dapat diwarnai (Norman \& Litwack, 1987; Kiernan 1990).

\section{Mekanisme serbuk pasak bumi sebagai pemacu/perangsang kerja sel-sel basofil} Mekanisme pasak bumi yang berfungsi sebagai pemacu/perangsang hormonal sehingga meningkatkan sebaran atau kerja sel-sel basofil penghasil hormon LH dan FSH pada hari ke 3 dapat dijelaskan sebagai berikut: Pasak bumi yang mengandung antara lain komponen phenol, tanin, polisakarida, glikoprotein dan mukopolisakarida, di dalamnya juga termasuk eurikomanon dan Iongilakton, (Ang, Hitotsuyanagi, \& Takeya, 2000) bekerja melalui pengaktifan aksis sumbu hipotalamus-pituatari atau hipofisa anterior dan adrenal (HPA) tikus jantan. Secara khusus, feromon tikus betina estrus dapat merangsang pelepasan $\mathrm{GnRH}$ dari hipotalamus tikus jantan (Vandenberg, 1983). Pengaktifan aksis sumbu HPA oleh senyawa tertentu dari pasak bumi (dengan adanya pelepasan $\mathrm{GnRH}$ ) selanjutnya merangsang atau memicu pelepasan hormon gonadotropin LH dan FSH dari kelenjar pituatari atau hipofisa anterior yang ditunjukkan oleh peningkatan sel-sel basofil. Kerja sinergi dari LH dan FSH lebih lanjut berlangsung pada jaringan testis khususnya pada tubulus seminiferus dan sel target yaitu sel-sel Leydig dan sel-sel Sertoli (Squires, 2003). Kedua sel-sel tersebut selanjutnya bersinergi misalnya dalam pembentukan hormon testosteron dan meningkatkan perkembangan sel-sel spermatogonia dalam proses spermatogenesis, yang akan menjadi spermatozoa pada jantan dewasa. Sementara itu, Norman dan Litwack (1987) menyebutkan kelimpahan jumlah spermatozoa dan peningkatan kadar testosteron akan juga menimbulkan peningkatan libido.

\section{Hipofisa berdasarkan mikrostruktur dan fungsi}

Mikromorfologi hipofisa terdiri atas: (1) Pars distalis/anterior atau hipofisa anterior, (2) Pars Intermedia, dan (3) Pars Nervosa atau hipofisa posterior. Secara morfologi hipofisa tampak secara relatif berwarna kelabu kemerah-merahan, berukuran kecil sekitar $10 \mathrm{~mm}(1 \mathrm{~cm})$ pada manusia dan pada tikus putih relatif lebih kecil lagi kira-kira sebesar ujung/pentul korek api. (Gambar 9) Hipofisa berhubungan dengan hipotalamus, hipofisa terletak pada otak tepat di belakang chiasma opticum dan merupakan bagian penonjolan dari dasar hipotalamus. 


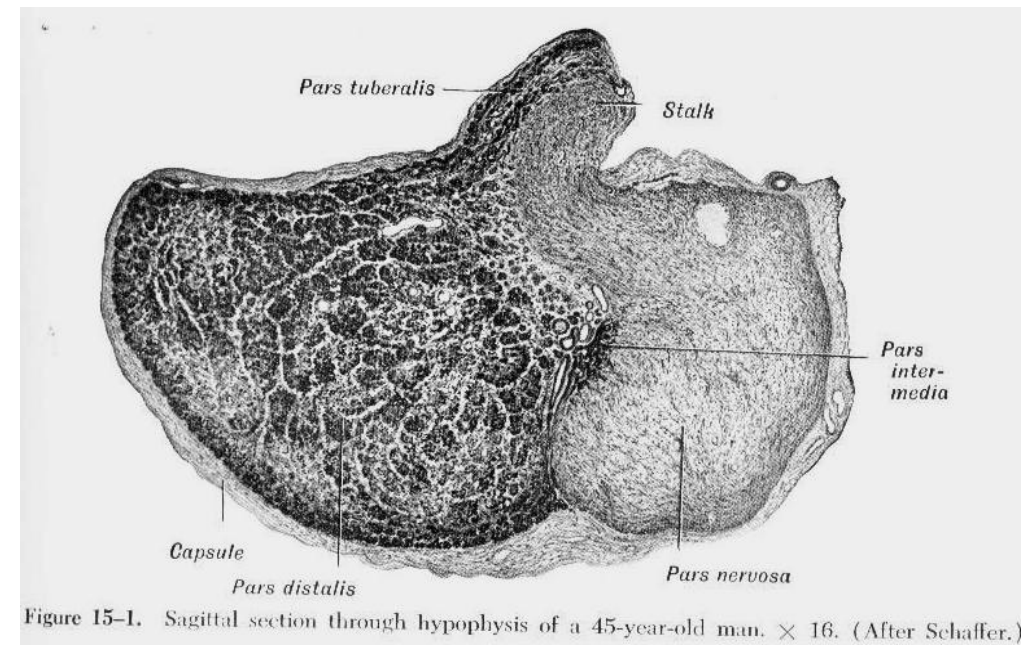

Gambar 9. Potongan sagital hipofisa pria, pembesaran $200 \times$ (Bloom and Don, 1962)

\section{KESIMPULAN}

Sebaran sel-sel asidofil dan basofil pada hipofisa mengalami perubahan setelah pemberian pasak bumi dosis seduhan $18 \mathrm{mg} / 200 \mathrm{~g}$ bb. Peningkatan yang nyata (uji Duncan, $\alpha=0,05$ ) rerata sel-sel basofil terjadi pada hari ke 3 pemberian pasak bumi dibandingkan dengan pemberian hari ke 1 dan kontrol hari 1 sampai hari 3 (27,9-35,2; 28,8-28,1). Dalam hal ini dapat disebutkan bahwa pasak bumi merupakan triger "cukup kuat" terhadap peningkatan sel-sel basofil hipofisa. Sebaliknya sebaran sel-sel asidofil mengalami penurunan setelah pemberian pasak bumi dosis seduhan 18 $\mathrm{mg} / 200 \mathrm{~g}$ bb. Penurunan yang nyata secara statistik rerata sel-sel asidofil terjadi pada hari ke 3 pemberian pasak bumi dibandingkan dengan kontrol hari 1 sampai hari $3(22,1-14,8 ; 21,2-21,9)$. Tetapi berlandaskan temuan tersebut belum dapat dijelaskan hormon LH ataukah hormon FSH yang meningkat secara bermakna, karena sel-sel basofil memproduksi hormon LH maupun FSH.

Berdasarkan hasil penelitian menunjukkan bahwa terjadi peningkatan sel-sel basofil pada hipofisa maka penelitian perlu dilanjutkan untuk mengkaji respon/tanggap sel-sel penghasil hormon LH dan FSH secara lebih khusus. Dengan melakukan penelitian lanjutan akan dapat diidentifikasi dan diketahui sel-sel penghasil hormon tertentu (LH atau FSH) yang meningkat. Berangkat dari saran tersebut, maka peneliti utama sedang melakukan penelitian lanjutan dengan metode imunohistokimia yang menggunakan bahan utama antara lain antibodi anti $\mathrm{LH}$, antibodi anti FSH, antibodi sekunder, dan DAB (Deamine Benzedine).

\section{REFERENSI}

Ang HH, Lee KL, \& Kiyoshi, M. (2004). Sexual arousal in sexually sluggish old male rats after oral administration of Eurycoma longifolia Jack - tongkat ali.

[Abstract] J. Basic Clinical Physiol. Pharmacol, 15(3-4):303-9. Penang Malaysia, School of Pharmaceutical Sciences, University Science Malaysia.

Ang HH, Hitotsuyanagi Y, \& Takeya K. (2000). Eurycolactones A-C, novel quassinoids from Eurycoma Iongifolia, Tetrahedron Pythochemistry, 41(35), 6849-6853. 
Ang HH. \& Lee KL. (2002). Effect of Eurycoma longifolia Jack on orientation activities in middle-aged male rats. [Abstract] FUNDAMENTAL \& Clinical Pharmacology, 16:6 hlm 470. [Desember 2002].

Anonim. (2006). Eurycoma longifolia William Jack. Diambil 15 Januari 2007, dari http://en.wikipedia.org/wiki/ Eurycoma_longifolia.

Bearden HJ, JW Fuquay, \& Scott TW. (2004). Applied animal reproduction. (6 ${ }^{\text {Th }}$ ) Upper Saddle River. New Jersey: Pearson Prentice Hall.

Bergman, A. (2000). Molecular Biology of the Cell, (4th ed). Texas, New York: Garland Science

Bloom W MD \& Don W Fawcett MD. (1962). A textbook of histology. Philadelphia, London: WB Saunders company.

Guyton AC. (1983). Buku ajar fisiologi kedokteran. Edisi 5, Alih bahasa Adji Dharma dan P Lukmanto. Jakarta, Penerbit Buku Kedokteran EGC.

Hembing WK. (1994). Tanaman berkhasiat obat di Indonesia. Jilid IV. Jakarta: Pustaka Kartini. HIm 131-132.

Johnson MH \& Barry JE. (1998). Essential reproduction. London, Carlton Victoria, Malden: Blackwell Science Inc.

Kardono LBS, Artanti N, Dewiyanti ID, \& Basuki T. (2003). Selected Indonesian medicinal plants: monographs and descriptions vol 1. Jakarta: PT. Gramedia Widiasarana Indonesia.

Kiernan JA. (1990). Histological and histochemical methods: Theory and Practice. $2^{\text {nd }}$ edition. New York: Pergamon Pr.

Norman AW \& Gerald, L.G. (1987). Hormones. London, Sidney, Tokyo: Academic Press Inc.

Pratomo, H. (1987). Efek rimpang kunyit (Curcuma domestica Val) sebagai anti piretik pada tikus putih jantan yang didemamkan [Skripsi Sarjana], Jakarta, Fakultas Biologi UNAS.

Pratomo H, Adi W, \& Edi, R. (2010). Model kerja afrodisiaka pasak bumi (eurycoma longifolia jack) pada tikus putih jantan [Laporan penelitian], Jakarta, Hibah Bersaing Dikti Kementrian Pendidikan Nasional 2010.

Vandenberg, JG. (1983). Pheromones and reproduction in mammals. Orlando: Academic press Inc. 